\title{
A Study of Magical Realism in Odiyan through the Collective Conscious of Paruthipulli
}

\author{
Dhema K.S, Shalini S, Aishwarya J Nair
}

Assistant Professor, Department of English, Sri Krishna Adithya College of arts and Science, Kovaipudur, Coimbatore, India

\begin{abstract}
Valluvanad was one of the final frontiers for western civilization. A land of immense beauty inhabited by people with strange traditions and practices which could at best is called Paganism. Hinduism which used to be practiced here and identified itself more with the plethora of indigenous beliefs than with the Vedas. Though Tippu Sultan's invasion and the subsequent British rule did expose them to the world outside, they remained in their small universe happy and content. Hence till the 1970's most of this region was untouched by modernity therefore unlike the rest of Kerala, still have Tharavads, sacred grooves called pambinkavu, velichapad and of course the rich mythology inherited from ancesters. One of the integral parts of this mythology is the supernatural world inhabited by Odiyans and practitioners of Odiyanseva. Odiyan and the stories associated with it is a major part of folklore. The Odiyan is a mythical figures really, a kind of shape shifting assassin from the stories of Northern Kerala. Odiyans are like any other creature of the night; like vampires, ghosts and succubi, creatures born out of fear and darkness. The legend is still alive though and people in rural areas do believe in the Odiyan.
\end{abstract}

Keywords-black magic, caste system, magical realism, professional assassins, the oil, the myth.

\section{INTRODUCTION}

"At the darkest hour of midnight, the woods whistle. And in the thick shadows, he skulks, waiting for his prey."

This myth revolves around the northern Kerala around 195060 s.At this time the chathurvarnya or the caste system was prevalent, based on which people were divided into Brahmana, Kshatriya, Nair, Ezhava, all of which were considered higher castes as compared to Pulaya, Paraya, Paana, Choklear, which were so called low castes. Kerala had an agrarian society. Within and among families, disputes and other family rifts were common. Among Nair and Ezhava families, this usually takes an appalling turn that could involve murder. But the high caste families won't indulge in the dirty work, which they entrust into the hands of Odiyans, hailing from the low caste families.

Odiyans are basically people who practice Odividya, a most evil form of black magic. Legends of Odiyans differ from place to pace, but basically they are of the same ilk: Odiyan is a sorcerer or animagus who has many supernatural abilities, some of which are the ability to run on four limbs and jump real high and climb trees quick, inhuman stamina, and of course the ability to shape shift. Even though has a rich variety legends and myths replete with all kind of monsters and spirits, Odiyan stands out because of the sheer terror it instills in the hearts of people even today. The legend of Odiyan is most popular in Paruthipulli, in the District Palakkad, which itself is quite eerie with all its forested areas and howling winds .Odiyan can be seen as a kind of contract killer. The illusionary power of Odiyan comes from the oil they apply on their earlobes. It is said to have been derived from the amniotic fluid of an unborn human fetus which was killed in the womb. Their targets were young women in their first pregnancy. During the day time while at work as the serf they would identify their victim and mark her off with a sign which was inscribed on the walls of the tharavad. At night, Pulaya or Paana would return as Odiyan and using his spells make the woman walk unconsciously in her sleep to a predetermined spot where he would be waiting. The woman's womb would be surgically opened with sharpened knifes made of bamboo and the fetus taken out. The fetus is then hung from a bamboo pole to harvest the fluid while the woman walked back home where she eventually bleed to death. The amount of oil obtained from one child would be too little, may be a few drops, but it could last for a handful of Odi tricks.

\section{THE PROFESSIONAL ASSASSINS}

The animagus then goes to a spot in some forested area which is on the way of the route through which the victim usually travels. In those days, there was no electricity and 
people usually walked about at night with a bunch of lit coconut leaves. This lighting is perfect for the Odiyan, who is believed to have had the ability to see in the dark, performs rituals which involves breaking the victim's spine in half. Then the Odiyan transforms into an animal-usually a bull, a calf, a big black dog or a black cat or sometimes an inanimate object like a wicker gate or even a stone and appears in the way of the victim. It is also believed that there there will be a pungent foul smell emanating from the mixture behind the Odiyan's ears. The curious part is, this animal will have some kind of deformity. For example, the bull may be three legged or the dog may have an extra eye. This deformity supposedly allures the victim making him want to have a closer look once he is near, the Odiyan, powered by the advantage of the element of surprise, kills his prey.

\section{CONCLUSION}

Rationalists have argued that Odiyans were actually people who wore animal skin to scare people, which of course is a possibility. Others say that Odiyans are actually skilled illusionists who can make a person see what they want them to, which is a possibility and also sounds interesting. Whether fact or fiction, one certain thing the Odiyan myth does is expose the dirty underbelly of the caste system that still extends vague ugly hands into the present day India. Valluvanad still believes in Odiyan and there are many deaths that are attributed to Odiyan seva. But in reality, with the modern education, the western life style and more importantly the emancipation of Panars and Pulayars there are no takers for the job. Moreover their patrons found new ways to settle disputes and the Odiyan died out without revealing many of its secrets like many other Indian traditions.

\section{REFERENCES}

[1] Kutty, Kannan. P, Odiyan, DC Books, July 2017

[2] Odiyan, Dir. VA Shrikumar Menon, 2018

[3] Haskell, Stephen.Kissel,Adam ed."Mythology The Creation of the Earth Summary and Analysis, Grade saver, 28 May 2008.

[4] Alappat, Sreedhara Menon, Kerala Charitham and Samskaram, DC Books, 2013.

[5] Mukundan. Pulayappattu. Calicut: Mathrubhumi Books, 2009. Print. 